\title{
Endovascular Embolization of Ruptured and Unruptured Posterior Circulation Aneurysms. A Multi-Factor Analysis
}

\author{
Kavernöz Sinüste Rüptür Gelişmiş ve Gelişmemis Posterior Dolaşım \\ Anevrizmalarının Endovasküler Embolizasyonu. Bir Multifaktöriyel \\ Analiz
}

Tomasz TYKOCKI ${ }^{1}$, Paweł NAUMAN ${ }^{1}$, Bogusław KOSTKIEWICZ ${ }^{2}$

${ }^{1}$ Institute Psychiatry and Neurology, Department of Neurosurgery, Warsaw, Poland

${ }^{2}$ Clinical Hospital of Ministry of Internal Affairs and Administration, Department of Neurosurgery, Warsaw, Poland

Correspondence address: Tomasz TYKOCKI / E-mail: ttomasz@mp.pl

\begin{abstract}
AIM: Complete aneurysm obliteration reduces the risk of rebleeding and is an important goal of the aneurysm treatment.

MATERIAL and METHODS: A retrospective analysis of 63 patients undergoing endovascular treatment of posterior circulation aneurysms. The occlusion rate was stratified to three groups: complete, incomplete and partial. In the analysis compared the influence of the selected characteristics: age, sex, WFNS grade, aneurysm location, size of the aneurysm dome and neck, neck to dome ratio, on the effectiveness of embolization in each group. A multi-factor analysis with probit model and linear regression was applied to assess the impact of all characteristics on the complete occlusion.

RESULTS: In the series of 63 single aneurysms, 51 were ruptured and 12 unruptured aneurysms. Complete occlusion was achieved in 36 $(57.1 \%)$, incomplete in $15(23.8 \%)$, partial in $12(19 \%)$ patients. In patients with the neck size of $1-2 \mathrm{~mm}$ the complete occlusion was in $75 \%$ (24/32) incomplete in 12,5\% (4/32), while when the neck size was $2-4 \mathrm{~mm}$ these rates were $38.7 \%(12 / 31)$ and $29 \%(9 / 31)$ respectively. The predictor of total occlusion in probit and linear regression model was only one independent variable, the narrow-neck size.
\end{abstract}

CONCLUSION: Multi-factor analysis found that the strongest predictor of the complete occlusion is the aneurysm neck size.

KEYWORDS: Aneurysm, Coiling, Posterior cerebral circulation

ÖZ

AMAÇ: Tam anevrizma obliterasyonu, tekrar kanama riskini azaltır ve anevrizma tedavisinin önemli bir hedefidir.

YÖNTEM ve GEREÇLER: Posterior dolaşım anevrizmalarının endovasküler tedavisi yapılan 63 hastanın retrospektif bir analizi. Oklüzyon oranı üç gruba katmanlandırıldı: tam, tam olmayan ve kısmi. Analiz şu seçilen özelliklerin etkisini karşılaştırdı: yaş, cinsiyet, WFNS sınıfı, anevrizma konumu, anevrizma kubbesi ve boynunun büyüklüğü, boyun-kubbe oranı ve her grupta embolizasyonun etkinliği. Tam oklüzyon üzerinde tüm özelliklerin etkisini değerlendirmek için Probit modeli ve lineer regresyonla multifaktöriyel bir analiz yapıldı.

BULGULAR: 63 hastalık anevrizma serisinde 51'i rüptüre uğramıştı ve 12'si uğramamıştı. Tam oklüzyon 36 (\%57,1), tam olmayan oklüzyon 15 $(\% 23,8)$, kısmi oklüzyon 12 (\%19) hastada elde edildi. Boyun büyüklüğü 1-2 mm olan hastalarda oklüzyon \%75 (24/32) hastada tam, \%12,5 (4/32) hastada tam değilken boyun büyüklüğü 2-4 mm olduğunda bu oranlar sırasıyla \%38,7 (12/31) ve \%29 (9/31) oldu. Probit ve lineer regresyon modelinde total oklüzyon prediktörü olarak dar boyun büyüklüğü şeklinde tek bağımsız değişken bulundu.

SONUÇ: Multifaktöriyel analiz tam oklüzyonun en kuvvetli prediktörünün anevrizma boyun büyüklüğü olduğunu gösterdi.

ANAHTAR SÖZCÜKLER: Anevrizma, Sarmal koyma, Posterior serebral dolaşım

\section{INTRODUCTION}

Aneurysms of posterior circulation account for $10 \%$ to $15 \%$ of all intracranial aneurysms $(4,16)$. In $8 \%$ of patients with aneurysmal subarachnoid hemorrhage $(\mathrm{SAH})$ the lesions were located at the posterior circulation (6). Neurosurgical approaches to the treatment of posterior circulation aneurysms are complicated by their anatomy (14), the mortality and morbidity of surgery for non-giant unruptured posterior circulation aneurysms was estimated as 3.0\% and $12.9 \%$ respectively (12). Therefore endovascular techniques are useful in the treatment of aneurysms in this region. The application of the Guglielmi electrolytically detachable coil has enabled a safer and more controlled form of cerebrovascular therapy (16). The aim of the endovascular treatment is complete occlusion of the aneurysm dome with coils and preventing blood flow into the sac. The degree of occlusion 
affects the postprocedural prognosis and increases the risk of rebleeding.

Authors report a retrospective analysis of 63 patients harboring ruptured and unruptured posterior circulation aneurysms treated with coil embolization. The aim of this study was to evaluate the significant predictors of total aneurysm occlusion including anatomical aneurysm features and patients characteristics.

\section{MATERIAL and METHODS}

A retrospective analysis of a total number of 63 patients (42 women and 21 men) with posterior circulation aneurysms who underwent diagnostic evaluation and endovascular treatment with the use of Gugliemi detachable coils at Clinical Hospital of Ministry of Interior in Warsaw between 1998 and 2003. In this review all patients' records, operative reports, angiographic, magnetic resonance, computed tomographic scans, outpatient charts, and telephone followup were subjected to detailed analysis. The World Federation of Neurological Surgeons (WFNS) grades were included for all patients. All the recruited patients underwent angiographic follow-up after 3 months.

\section{Patients selection}

All the patients were qualified for endovascular coil embolization of posterior circulation aneurysms by a team of doctors consisting of a neurosurgeon, neuroradiologist and anesthesiologist. The endovascular procedure was undertaken regardless of clinical status, WFNS grades and the time elapsed since the origin of SAH. However, efforts were made to perform the procedure within 72 hours The diagnosis of $\mathrm{SAH}$ was made based on the computed tomography in emergency department. Patients with concomitant intracerebral hemorrhage were referred to the neurosurgical department and excluded from the review. In cases with unraptured aneurysms elective angiography was performed.

\section{Statistical analysis}

All the results were statistically analyzed using the computer software "Statistical Package SPSS 10". The following statistical techniques were used:

1) $\mathrm{Chi}^{2}$ test - to check the compliance schedules of results; 2) univariate analysis of variance - to test the significance of differences between means for parametric variables; 3 ) Kruskal-Wallis test - to test the significance of differences between the ranks for nonparametric variables; 4) probit model to assess opportunities of complete aneurysm occlusion; 5) linear regression analysis - to determine the influence of tested variables on the efficacy of treatment. The Kolmogorov-Smirnov test was used to check normality distribution of variables, and Levene's test for homogeneity of variance. The lowest level of significance was $p<0.05$.

The analysis focuses on examining the impact of basic patient characteristics (age, sex, WFNS grade, aneurysm location, size of the aneurysm dome and neck, the neck to dome ratio) on the effectiveness of embolization. For research purposes the degree of embolization was stratified to three groups:

I. Patients with the complete embolization (100-95\%), when the dome and neck were densely filled with coils

II. Patients with the incomplete embolization (95\%-90\%), when neck remnant was observed

III. Patients with partial embolization (below 90\%), when there was loose packing and persistent opacification of neck or dome remnant.

The analysis was proceeded in two stages. The first compared the influence of mean values of the selected characteristics on the degree of embolization in each group. In the second stage a multi-factor analysis with probit model was applied to assess the impact of all characteristics on the occlusion rate.

In this binary model the dependent variable (occlusion degree) can be graded as 1 (complete embolization, 100\%) or 0 (incomplete embolization, less than $100 \%$ ), and patients characteristics as the continuous independent variables.

Linear regression analysis was performed additionally in order to verify whether the studied factors (age, sex, WFNS grade, aneurysm location, size of the aneurysm dome, and the neck to dome ratio) are important predictors of the effectiveness of embolization.

\section{RESULTS}

In the series of 63 single aneurysms, in 51 cases SAH was observed and in 12 were unruptured aneurysms. The most common location was the basilar tip 60.3\% (38/63), the second was posterior inferior cerebellar artery 19\% (12/63), followed by the superior cerebellar artery $14.3 \%(9 / 63)$. The size of the dome and neck was determined on the arteriography, 27 $(42,9 \%)$ aneurysms were small with the diameter of 2-6 mm, $26(41.3 \%)$ medium 6-12 mm, and 10 (15.8\%) large 12-24 $\mathrm{mm}$. Of SAH patients, WFNS Grade I was present in 21 (41.2\%) patients, grade II in 14 (27.5\%), III in 10 (19.6\%) and IV/V in 6 (11.8\%) (Table I).

The degree of aneurysmal dome occlusion was determined by the operating neurosurgeon and was obtained from the dictated operative reports. Complete occlusion was achieved in $36(57,1 \%)$ patients, incomplete in $15(23.8 \%)$ and partial in 12 (19\%) patients. In patients with a neck size of 1-2 mm the rate of complete embolization was $75 \%$ (24/32) and incomplete $12.5 \%$ (4/32), while when the neck size was $2-4 \mathrm{~mm}$ these rates were $38.7 \%(12 / 31)$ and $29 \%(9 / 31)$ respectively. In 12 patients the neck to dome ratio was less than 1:2, and in this group no total aneurysm embolization was achieved, but when this ratio was greater than 1:2 total occlusion was observed in $70.6 \%(36 / 51)$ (Table II). Patients from group I had significantly smaller mean dome and neck size. Also the mean neck to dome ratio was higher in group I $(3.3 \pm 0.7)$ than in II $(2.9 \pm 1.3)$ and III ( $2 \pm 1.8)$. Age appeared to be a differentiating factor concerning the occlusion rate. The mean age in the group with partial embolization (below 90\%) (50.6 years) 
Table I: Preoperative Characteristics of Patients

\begin{tabular}{|c|c|c|}
\hline Age (years) & $\mathbf{n}$ & $\%$ \\
\hline $22-35$ & 12 & 19 \\
\hline $36-50$ & 42 & 66.7 \\
\hline $51-65$ & 9 & 14.3 \\
\hline \multicolumn{3}{|l|}{ Gender } \\
\hline Female & 42 & 66.7 \\
\hline Male & 21 & 33.3 \\
\hline \multicolumn{3}{|l|}{ Aneurysm dome size } \\
\hline Small 2-6 mm & 27 & 42.9 \\
\hline Medium 6-12mm & 26 & 41.3 \\
\hline$>12-24 \mathrm{~mm}$ & 10 & 15.8 \\
\hline \multicolumn{3}{|l|}{ Neck to dome ratio } \\
\hline Less than $1: 2$ & 12 & 19 \\
\hline More than 1:2 & 51 & 80.9 \\
\hline \multicolumn{3}{|l|}{ Localization } \\
\hline Basilar bifurcation & 38 & 60.3 \\
\hline Posterior inferior cerebellar artery & 12 & 19 \\
\hline Superior cerebellar artery & 9 & 14.3 \\
\hline Mid-portion of basilar artery & 2 & 3.2 \\
\hline Distal posterior cerebral artery & 2 & 3.2 \\
\hline \multicolumn{3}{|l|}{ Aneurysm neck size } \\
\hline $1-2 \mathrm{~mm}$ & 30 & 47.6 \\
\hline $2-4 \mathrm{~mm}$ & 24 & 38.1 \\
\hline$>4 \mathrm{~mm}$ & 9 & 14.3 \\
\hline \multicolumn{3}{|l|}{ WFNS grade } \\
\hline 1 & 21 & $41.2 \%$ \\
\hline II & 14 & $27.5 \%$ \\
\hline III & 10 & $19.6 \%$ \\
\hline IV iV & 6 & $11.8 \%$ \\
\hline
\end{tabular}

was significantly higher than in the other two groups (41 and 41,5 years respectively) (Table III). Percentage of the total embolization in WFNS classification was the highest in grade I at $71.4 \%(15 / 21)$; followed by II at $50 \%(7 / 14)$, III at 30\% (3/10) and IV/V at $33.3 \%(2 / 6)$ (Table II).

At the early postoperative period 2 patients died due to cerebral vasospasm and pneumonia, and both were classified as WFNS grade IV/V. Partial embolization was detected at 3-month angiographic follow up in 14 patients and additional coils were inserted to completely seal off the aneurysm.

Multi-factor evaluation of the effectiveness of embolization with the probit analysis indicates the significance of all independent variables (characteristics) taken together in the model $(p<0.001)$. However, the predictor of total occlusion seemed only one independent variable, the neck size (parameter estimate $=-0.134 ; z=0.535 ; p=0.001$ ). A negative value of this variable indicated that the smaller the size of the neck, the greater chance of successful embolization (Table IV).

The analysis of linear regression was statistically significant $(p<0.0001)$ and results were consistent with those from the probit model. The full regression model explains $53 \%$ of the variance of the variable - effectiveness of embolization (Beta $=-0.73 ; \mathrm{t}=8.35 ; \mathrm{p}<0.001)$ and only one of the factors (aneurysm neck size) was statistically significant ( $p<0.0001$ ). The contribution of other factors in the explanation of the variance was slight (Beta not higher than 0.1) (Table IV).

\section{DISCUSSION}

The authors retrospectively reviewed 63 patients with posterior circulation aneurysms treated with endovascular coiling. The analysis was designed to investigate the predictors of the effectiveness of the embolization. Only the aneurysm neck size maintained statistical significance when adjusted for all other variables. In the multi-variant model, none of the

Table II: Data Summary of Patients after Posterior Circulation Aneurysm Endovascular Treatment

\begin{tabular}{|c|c|c|c|}
\hline & \multicolumn{3}{|c|}{ Occlusion rate * } \\
\hline & $100-95 \%$ & $95-90 \%$ & $<90 \%$ \\
\hline General & $36(57.1 \%)$ & $15(23.8 \%)$ & $12(19 \%)$ \\
\hline \multicolumn{4}{|l|}{ Neck to dome ratio } \\
\hline Less than 1:2 & 0 & $3(4.8 \%)$ & $9(14.3 \%)$ \\
\hline More than 1:2 & $36(57.1 \%)$ & $12(19 \%)$ & $3(4.8 \%)$ \\
\hline \multicolumn{4}{|c|}{ Aneurysm neck size } \\
\hline $1-2 \mathrm{~mm}$ & $24(38.1 \%)$ & $4(6.3 \%)$ & $2(3.2 \%)$ \\
\hline $2-4 \mathrm{~mm}$ & $12(19 \%)$ & $9(14.3 \%)$ & $3(4.8 \%)$ \\
\hline$>4 \mathrm{~mm}$ & $2(3.2 \%)$ & $4(6.3 \%)$ & $3(4.8)$ \\
\hline \multicolumn{4}{|l|}{ WFNS grade } \\
\hline 1 & $15(23.8 \%)$ & $4(6.3 \%)$ & $2(3.2 \%)$ \\
\hline II & $7(11.1 \%)$ & $5(7.9 \%)$ & $2(3.2 \%)$ \\
\hline III & $3(4.8 \%)$ & $4(6.3 \%)$ & $3(4.8 \%)$ \\
\hline IV and V & $2(3.2 \%)$ & $2(3.2 \%)$ & $2(3.2 \%)$ \\
\hline
\end{tabular}

* Percentage of all 63 participants in the study in parenthesis. 
Table III: Postprocedural Outcomes Concerning the Degree of Embolization

\begin{tabular}{|c|c|c|c|}
\hline & $100-95 \%$ & $95-90 \%$ & $<90 \%$ \\
\hline Aneurysm dome size & $6.1 \mathrm{~mm} \pm 2.73$ & $10.9 \mathrm{~mm} \pm 4$ & $11.6 \mathrm{~mm} \pm 5.4$ \\
\hline Aneurysm neck size & $2 \mathrm{~mm} \pm 0.8$ & $4 \mathrm{~mm} \pm 1$ & $6.1 \mathrm{~mm} \pm 3$ \\
\hline Neck to dome ratio & $3.3 \pm 0.7$ & $2.9 \pm 1.3$ & $2 \pm 1.8$ \\
\hline Age & $41.5 \pm 10.4$ & $41 \pm 9.5$ & $50.6 \pm 8.9$ \\
\hline WFNS grade & $1.3 \pm 1.3$ & $0.3 \pm 0.5$ & $2.2 \pm 1.5$ \\
\hline
\end{tabular}

Table IV: Probit Model and Linear Regression of Significant Predictors Related to Total Aneurysm Occlusion

\begin{tabular}{|c|c|c|c|c|c|c|c|c|}
\hline \multicolumn{5}{|c|}{ Probit model ${ }^{1}$} & \multicolumn{4}{|c|}{ Linear regression ${ }^{2}$} \\
\hline Factor & $\begin{array}{c}\text { Parameter } \\
\text { estimate }\end{array}$ & $\begin{array}{l}\text { Standard } \\
\text { error }\end{array}$ & z-value & $p$ & Factor & Beta & $\mathbf{t}$ & $\mathbf{p}$ \\
\hline Age & 0.030 & 0.006 & 0.470 & 0.641 & Neck size & -0.73 & -8.35 & 0.0001 \\
\hline Gender & 0.074 & 0.120 & 0.615 & 0.542 & Gender & 0.1 & 1.07 & 0.29 \\
\hline \multicolumn{5}{|c|}{ Localization } & \multirow{2}{*}{ Localization } & \multirow{2}{*}{0.08} & \multirow{2}{*}{0.92} & \multirow{2}{*}{0.36} \\
\hline BA-TIP & 0.098 & 0.333 & 0.294 & 0.770 & & & & \\
\hline SCA & 0.252 & 0.353 & 0.715 & 0.478 & Dome size & -0.06 & -0.46 & 0.65 \\
\hline VA & 0.216 & 0.355 & 0.607 & 0.547 & Age & 0.04 & 0.44 & 0.66 \\
\hline PCA & 0.386 & 0.405 & 0.955 & 0.344 & WFNS grade & 0.01 & 0.13 & 0.9 \\
\hline \multicolumn{5}{|c|}{ Aneurysm features } & & & & \\
\hline Dome size & -0.014 & 0.018 & -3.818 & 0.442 & & & & \\
\hline Neck size & -0.134 & 0.035 & 0.535 & 0.001 & & & & \\
\hline \multicolumn{5}{|c|}{ WFNS grade } & & & & \\
\hline I & 0.069 & 0.129 & 0.535 & 0.595 & & & & \\
\hline II & 0.084 & 0.209 & 0.400 & 0.691 & & & & \\
\hline III & 0.167 & 0.171 & 0.975 & 0.334 & & & & \\
\hline IV & 0.429 & 0.312 & 1.378 & 0.174 & & & & \\
\hline V & 0.358 & 0.347 & 1.031 & 0.308 & & & & \\
\hline
\end{tabular}

BA-TIP - basilar tip; SCA - superior cerebellar artery; VA-vertebral artery; PCA-posterior cerebral artery

Results of statistical models

1. $F^{13,49}=4,17 ; p=0,0001 ; R^{2}=0,525$ 2. $F=69,71 ; p=0,0001 ; R^{2}=0,53$.

factors like age, gender, aneurysm dome size, localization or WFNS grade seemed to predict the total occlusion of the aneurysm. Total occlusion was achieved in $57.2 \%$ of the cases and in $81 \%$ the occlusion rate was more than $90 \%$. When each factor was analysed separately, a significantly smaller mean dome and neck size was observed in the group with total occlusion compared with other groups. Successful embolization was correlated with higher mean neck to dome ratio and younger age.

Multiple case series review in the literature show the rate of complete posterior circulation aneurysm occlusion varies from $42 \%$ to $87.5 \%$ ( $\geq 95 \%$ occlusion) (1-7). In the International Subarachnoid Aneurysm Trial (ISAT), $66 \%$ of the cases after endovascular coiling had complete angiographic occlusion, $26 \%$ subtotal occlusion or a neck remnant, and $8 \%$ incomplete occlusion with aneurysm refilling. In the clipping arm $82 \%$ were completely occluded, $12 \%$ had a neck remnant, and $6 \%$ were incompletely occluded. These results favor the neurosurgical treatment on the degree of aneurysm occlusion (7). Lambert et al. reported that higher aneurysm neck size was found to be significantly correlated with a lower final occlusion. In the group with the neck size below $4 \mathrm{~mm}$ the rate of total occlusion was $62 \%$ and in size 4 to $6 \mathrm{~mm} 38 \%$. A similar relation was identified for the aneurysm dome size and in the group with dome size $<9 \mathrm{~mm}$ total occlusion was $66 \%$ and in those with size $>9 \mathrm{~mm}$ the rate was $38 \%$ (5).

In the series of 275 patients reported by Pandey et al. (10) the evaluation of clinical factors (age, sex, location, aneurysmal size, presence of shunt, initial occlusion, and coil type) showed that only Hunt Hess grade and the absence of shunt were significant predictors of good clinical outcome. In the same study there was a strong relationship between the degree of initial occlusion and subsequent recurrence and reached $15.2 \%$ in the group with complete occlusion 
and $54.5 \%$ in incomplete occlusion. The occlusion degree plays a critical role in terms of the recurrence risk due to the inappropriate hemodynamic conditions in incompletely occluded aneurysms leading to blood flow, lack of thrombus and scar organization. The comparison of anterior circulation with posterior circulation aneurysms found that excellent or good clinical outcome was $65,9 \%$ in posterior circulation and $84,5 \%$ in anterior circulation for both surgically and endovascularly treated patients. In the endovascular group, an excellent or good outcome occurred in $81.5 \%$ of anterior circulation lesions and in only $54.2 \%$ of posterior circulation lesions, and in the clipping group these results were $85.3 \%$ and $75.3 \%$ respectively.

Mortasini et al. did not find any correlation between the neck size and occlusion rate, and according to their report the only predictor was the dome size (8). Another study analyzing the endovascular treatment of basilar tip aneurysms using a multivariate binary logistic regression indicated that aneurysmal neck size was the only independent predictor of initial occlusion rate (15) and revascularization, which is consistent with the results of this report.

Another issue worth mentioning is endovascular treatment of wide-neck intracranial aneurysms which still remains a technically challenging procedure. Wide neck aneurysms are defined as those having absolute neck diameter of $4.0 \mathrm{~mm}$ and more or dome-to-neck ratio less than 2. Due to these anatomical conditions there is a higher risk of recanalization, regrowth, rerupture and coils protrusion after embolization. Significant progress in endovascular techniques has led to the application of new therapeutic strategies including balloon remodeling, stent-assisted coiling, sole stent placement or Onyx liquid embolic agent to reconstruct the parent artery.

Occlusion rates with the balloon remodeling technique were estimated to be over $70 \%$ in current series. Moret et al. (17) reported total occlusion in $77 \%$ and partial occlusion in $17 \%$ cases and according to Youn at al. (18) these results were $91.2 \%$ and $8,8 \%$ respectively. The comparison of remodeling technique and standard coiling showed that the initial total occlusion was at higher rates in the remodeling group (73\% vs. $49 \%)$, and these results remained stable at follow up (72\% in the remodeling group and $54 \%$ the standard coiling group) (19).

In a systematic review of the stent-assisted coiling in ruptured aneurysms with different types of stents, 130 of 206 cases (63\%) had complete occlusion, $39(19 \%)$ a neck remnant, $26(13 \%)$ had residual patency in the aneurysm and $11(5 \%)$ had no occlusion (20). Interestingly, Fragen at. al observed progressive complete occlusion rates from initial $28 \%$ to $54 \%$ at 21- month follow-up after stent-assisted coiling with the Enterprise stent (21).

In two large European trials with Onyx liquid embolic agent complete occlusion was reported in $79-87,5 \%$ of aneurysms $(22,23)$. Overall recanalization rate of wide-neck aneurysms was $36 \%$, when combined with adjuvant stent placement this rate decreased to $4 \%(23)$.

\section{CONCLUSIONS}

During the last decades endovascular techniques become a therapeutic standard in the treatment of posterior circulation aneurysms with lower risks and technical difficulties in comparison with microsurgical procedures. This study shows that an endovascular approach allows for the total aneurysm occlusion in the majority of patients. Multi-factor analysis found that the strongest predictor of complete occlusion is the narrow-neck size.

\section{DISCLOSURE}

The authors have no personal financial or institutional interests in any of the drugs, materials, or devices described in this article.

\section{REFERENCES}

1. BavinzskiG, Richling B, Gruber A, Killer M, Levy D: Endosaccular occlusion of basilar artery bifurcation aneurysms using electrically detachable coils. Acta Neurochir (Wien) 134: 184-189,1995

2. Eskridge JM, Song JK: Endovascular embolization of 150 basilar tip aneurysms with Guglielmi detachable coils: Results of the Food and Drug Administration multicenter clinical trial. J Neurosurg 89:81-86,1998

3. Gruber DP, Zimmerman GA, Tomsick TA, van Loveren HR, Link MJ, Tew JM Jr: A comparison between endovascular and surgical management of basilar artery apex aneurysms. J Neurosurg 90:868-874,1999

4. Guglielmi G, Viñuela F, Duckwiler G, Dion J, Lylyk P, Berenstein A, Strother C, Graves V, Halbach V, Nichols D: Endovascular treatment of posterior circulation aneurysms by electrothrombosis using electrically detachable coils. J Neurosurg 77:515-524,1992

5. Lempert TE, Malek AM, Halbach VV, Phatouros CC, Meyers PM, Dowd CF, Higashida RT: Endovascular treatment of ruptured posterior circulation cerebral aneurysms. Clinical and angiographic outcomes. Stroke 31:100-110, 2000

6. Molyneux A, Kerr R; International Subarachnoid Aneurysm Trial (ISAT) Collaborative Group, Stratton I, Sandercock P, Clarke M, Shrimpton J, Holman R: International Subarachnoid Aneurysm Trial (ISAT) of neurosurgical clipping versus endovascular coiling in 2143 patients with ruptured intracranial aneurysms: A randomized trial. J Stroke Cerebrovasc Dis 11(6):304-314, 2002

7. Molyneux AJ, Kerr RS, Yu LM, Clarke M, Sneade M, Yarnold JA, Sandercock P: International Subarachnoid Aneurysm Trial (ISAT) Collaborative Group: International subarachnoid aneurysm trial (ISAT) of neurosurgical clipping versus endovascular coiling in 2143 patients with ruptured intracranial aneurysms: A randomised comparison of effects on survival, dependency, seizures, rebleeding, subgroups, and aneurysm occlusion. Lancet 366(9488):809-817, 2005 
8. Mordasini P, Schroth G, Guzman R, Barth A, Seiler RW, Remonda L: Endovascular treatment of posterior circulation cerebral aneurysms by using Guglielmi detachable coils: A 10-year single-center experience with special regard to technical development. AJNR Am J Neuroradiol 26(7): 1732-1738, 2005

9. Ogilvy CS, Cheung AC, Mitha AP, Hoh BL, Carter BS: Outcomes for surgical and endovascular management of intracranial aneurysms using a comprehensive grading system. Neurosurgery 59(5):1037-1042, 2006

10. Pandey AS, Koebbe C, Rosenwasser RH, Veznedaroglu E: Endovascular coil embolization of ruptured and unruptured posterior circulation aneurysms: Review of a 10-year experience. Neurosurgery 60(4):626-636, 2007

11. Pierot L, Boulin A, Castaings L, Rey A, Moret J: Selective occlusion of basilar artery aneurysms using controlled detachable coils: Report of 35 cases. Neurosurgery 38: 948-954, 1996

12. Raaymakers TW, Rinkel GJ, Limburg M, Algra A: Mortality and morbidity of surgery for unruptured intracranial aneurysms: A meta-analysis. Stroke 29:1531-1538, 1998

13. Raymond J, Roy D: Safety and efficacy of endovascular treatment of acutely ruptured aneurysms. Neurosurgery 41:1235-1246, 1997

14. Taylor CL, Kopitnik TA Jr, Samson DS, Purdy PD: Treatment and outcome in 30 patients with posterior cerebral artery aneurysms. J Neurosurg 99:15-22, 2003

15. Vallee JN, Aymard A, Vicaut E, Reis M, Merland JJ: Endovascular treatment of basilar tip aneurysms with Guglielmi detachable coils: Predictors of immediate and long-term results with multivariate analysis 6-year experience. Radiology 226(3): 867-879, 2003

16. Vinuela F, Duckwiler G, Mawad M: Guglielmi detachable coil embolization of acute intracranial aneurysm: Perioperative anatomical and clinical outcome in 403 patients. J Neurosurg $86: 475-482,1997$
17. Moret J, Cognard C, Weill A, Castaings L, Rey A: Reconstruction technic in the treatment of wide-neck intracranial aneurysms. Long-term angiographic and clinical results. Apropos of 56 cases. J Neuroradiol 24(1):30-44, 1997

18. Youn SO, Lee Jl, Ko JK, Lee TH, Choi CH: Endovascular treatment of wide-necked intracranial aneurysms using balloonassisted technique with hyper form balloon. J Korean Neurosurg Soc 48(3):207-212, 2010

19. Shapiro M, Babb J, Becske T, Nelson PK: Safety and efficacy of adjunctive balloon remodeling during endovascular treatment of intracranial aneurysms: A literature review. AJNR Am J Neuroradiol 29(9):1777-1781, 2008

20. Bodily KD, Cloft HJ, Lanzino G, Fiorella DJ, White PM, Kallmes DF: Stent-assisted coiling in acutely ruptured intracranial aneurysms: A qualitative, systematic review of the literature. AJNR Am J Neuroradiol 32(7):1232-1236, 2011

21. Fargen KM, Hoh BL, Welch $B$, Lee Pride $G$, Lanzino $G$, Boulos AS, Carpenter JS, Rai A, Veznedaroglu E, Ringer A, Rodriguez-Mercado R, Kan P, Siddiqui A, Levy El, Mocco J: Long-term results of epnterprise stent-assisted coiling of cerebral aneurysms. Neurosurgery Apr 2 2012; DOI: 10.1227/ NEU.0b013e3182571953

22. Cekirge HS, Saatci I, Ozturk MH, Cil B, Arat A, Mawad M, Ergungor F, Belen D, Er U, Turk S, Bavbek M, Sekerci Z, Beskonakli E, Ozcan OE, Ozgen T: Late angiographic and clinical follow-up results of 100 consecutive aneurysms treated with Onyx reconstruction: Largest single-center experience. Neuroradiology 48(2):113-126, 2006

23. Molyneux AJ, Cekirge S, Saatci I, Gál G: Cerebral Aneurysm Multicenter European Onyx (CAMEO) trial: Results of a prospective observational study in 20 European centers. AJNR Am J Neuroradiol 25(1):39-51, 2004 